\title{
SOĞUK KURUTULMUŞ TAVUK ETİ DİLİMLERİNİN BAZI KALİTE ÖZELLIKLERİ
}

\author{
Elif Aykın Dinçer* \\ Akdeniz Üniversitesi Mühendislik Fakültesi Gıda Mühendisliği Bölümü, Antalya, Türkiye
}

Geliş / Received: 16.10.2019; Kabul / Accepted: 07.02.2020; Online bask1 / Published online: 27.02.2020

Aykın Dinçer, E. (2020). Soğuk kurutulmuş tavuk eti dilimlerinin bazı kalite özellikleri. GIDA (2020) 45(2) 262-274 doi: 10.15237/gida.GD19135

Aykem Dincer, E. (2020). Some quality properties of cold dried chicken meat slices. GIDA (2020) 45(2) 262-274 doi: 10.15237/gida.GD19135

\section{ÖZ}

Bu çalışmada; soğuk kurutma sistemi kullanılarak elde edilen kurutulmuş tavuk göğüs eti dilimlerinin bazı kalite özelliklerinin belirlenmesi amaçlanmıştır. Bu amaca yönelik olarak; tavuk göğüs eti dilimleri $(85 \mathrm{~mm} x$ $34 \mathrm{~mm}$ x $2 \mathrm{~mm})$, kızgın buharla pastörize edildikten sonra farklı düşük sıcaklık $\left(10,15\right.$ ve $\left.20^{\circ} \mathrm{C}\right)$ ve hava akış hızlarında (3, 4 ve $5 \mathrm{~m} / \mathrm{s})$ kurutulmuştur. Soğuk kurutulmuş et dilimlerinin ortalama nem içeriğinin $\% 37$, su aktivitesi $\left(\mathrm{a}_{\mathrm{w}}\right)$ değerinin $0.89, \mathrm{pH}$ değerinin 6.15 ve tiyobarbitürik asit reaktif maddeleri (TBARS) değerinin ise $23.66 \mu \mathrm{mol} \mathrm{MDA} / \mathrm{kg}$ olduğu tespit edilmiştir. Düşük sıcaklık ve yüksek hava akış hızında örneklerin daha açık renkli (daha yüksek $L^{*}$ ve düşük $a^{*}$ değeri) olduğu belirlenmiştir. Düşük hava akış hızında kurutulmuş dilimlerinin mikrobiyolojik kalitelerinin daha yüksek olduğu tespit edilmiştir. Duyusal değerlendirmede ise en yüksek genel beğeni puanına $10^{\circ} \mathrm{C}$ ve $5 \mathrm{~m} / \mathrm{s}$ 'de kurutulan örneklerin sahip olduğu belirlenmiştir.

Anahtar kelimeler: Hava akış hızı, kalite, kurutulmuş tavuk eti, soğuk kurutma

\section{SOME QUALITY PROPERTIES OF COLD DRIED CHICKEN MEAT SLICES}

\section{ABSTRACT}

In this study, it was aimed to determine some quality characteristics of dried chicken breast meat slices obtained from using cold drying system. On this purpose, chicken breast meat slices $(85 \mathrm{~mm} x$ $34 \mathrm{~mm} \times 2 \mathrm{~mm}$ ) were pasteurized with hot steam and then dried at different low temperatures (10, 15 and $\left.20^{\circ} \mathrm{C}\right)$ and air flow velocities $(3,4$ and $5 \mathrm{~m} / \mathrm{s})$. It was determined that the average moisture content of cold-dried meat slices was $37 \%$, water activity $\left(\mathrm{a}_{\mathrm{w}}\right)$ value was $0.89, \mathrm{pH}$ value was 6.15 and thiobarbituric acid reactive substances $(T B A R S)$ value was $23.66 \mu \mathrm{mol} \mathrm{MDA} / \mathrm{kg}$. At low temperature and high air flow velocity, the samples were found to be lighter (higher $L^{*}$ and lower $a^{*}$ value). Microbiological quality of slices dried at low air flow velocity was higher. In sensory evaluation, the samples dried at $10^{\circ} \mathrm{C}$ and $5 \mathrm{~m} / \mathrm{s}$ had the highest score of overall acceptability.

Keywords: Air flow velocity, quality, dried chicken meat, cold drying

${ }^{*}$ Yazışmalardan sorumlu yazar/ Corresponding author

$\square$ elifaykin@akdeniz.edu.tr $\quad(+90) 2422274400-4345$

县 $(+90) 2422274564$

Elif Aykın Dinçer; ORCID no: 0000-0003-4427-9819 


\section{GİRİ̧̧}

Geçmişten günümüze kadar insanlar, gıdaların uzun süre bozulmadan saklanmasını sağlayacak muhafaza yöntemlerini araştırmış ve yeni muhafaza yöntemleri geliştirmeye çalışmıştır. Hayvansal gidalar arasında önemli bir yere sahip olan et için de çeşitli muhafaza teknikleri kullanılmış ve geliştirilmiştir. Etlerin tuzlandıktan sonra güneşte kurutulması bilinen en eski muhafaza yöntemlerinden biridir. Geleneksel olarak üretilen kurutulmuş et ürünlerine Orta Asya ve Türkiye'de pastrma, Kuzey Amerika'da jerky ve pemmican, Brezilya'da carne-de-sol, İspanya ve Meksika'da cecina, Küba'da tasajo, Güney Afrika'da biltong, Kuzey Afrika'da kaddid ve Çin'de rougan ve roupu örnek verilebilir (Aykın-Dinçer ve Erbaş, 2019a; b; c; Aykın-Dinçer vd., 2019).

Tuzlama işlemi, genellikle etin raf ömrünü uzatma ve tat, aroma ve tekstürel özelliklerini geliştirme amaciyla uygulanmaktadır. Özellikle kurutulmuş et ürünlerinin üretiminde su aktivitesi $\left(\mathrm{a}_{\mathrm{w}}\right)$ değerini düşürerek kurumayı hızlandırdığı için, ön işlem basamağ1 olarak yer almaktadır. Tuzlama işlemi kuru ve yaş (salamura) tuzlama olmak üzere farklı şekilde yapilabilmektedir. Kuru tuzlama en eski yöntemlerden biri olup, genellikle "pasttrma", "bacon" ve "bam” gibi kür edilmiş, pişirilmiş veya kurutulmuş et üretiminde uygulanmaktadır. Bu yöntemde et parçasının yüzeyine homojen dağılacak şekilde uygulanan kuru tuz, kasın yapısında bulunan suda çözünmektedir. Et yüzeyinde tuzun çözünmesi ve bu çözeltinin konsantrasyonu, tuzun et parçasının merkezine doğru nüfuz etmesini ve etin merkezindeki suyun da yüzeye doğru hareket etmesini düzenleyen ana faktörlerden biridir (Aykın Dinçer ve Erbaş, 2018).

Genel olarak kurutma, herhangi bir üründeki; mikrobiyolojik, biyokimyasal ve kimyasal faaliyetleri kontrol altına almak için hijyenik şartlar altında ürünün bünyesinde bulunan suyun uygun sicaklık ve/veya nispi nem farklılı̆̆1 prensibi ile üründen uzaklaştırılması ve ürünün $\mathrm{a}_{\mathrm{w}}$ değerinin düşürülmesi olarak tanımlanmaktadır (Anonim, 2019; Aykın-Dinçer ve Erbaş, 2019c). Yaygın olarak kullanılan kurutma yöntemleri güneşte kurutma, sicak hava ile kurutma, dondurarak kurutma, vakumla kurutma, ozmatik dehidrasyon, mikrodalga, sprey kurutma ve kimyasal maddelerin yardımı ile kurutmadır (Doğan, 2001; Vega, 2007). Bu yöntemlerle, mikrobiyel ve kimyasal bozulmalar önlenerek gidaların uzun süre korunması ve paketleme, depolama ve ulaşım masraflarının da azalması sağlanmaktadır (Traffano-Schiffo vd., 2014). Soğuk kurutma işlemi, soğuk havanın kurutma ünitesi girişinde daha soğuk bir yüzeye çarptırlarak nemini bırakması sağlandıktan sonra elde edilen soğuk ve su buharı içeriği azaltılmıs havanın kurutma işleminde kullanılması prensibine dayanmaktadır (Aykın-Dinçer ve Erbaş, 2019b). Sıcaklığa hassas gıdalar için, düşük sıcaklıkta kurutma işlemi raf ömrünü uzatan ve bozulmayı önleyen gida koruma tekniklerinden biridir (Kilic, 2009). Bu kurutma tekniği uzun işlem süresine rağmen, ürünün kimyasal, mikrobiyolojik ve duyusal kalitesinde olumsuz değişimlere yol açmamaktadır (Aykın-Dinçer ve Erbaş, 2019a). Düşük sıcaklıkta $\left(<20^{\circ} \mathrm{C}\right)$ kurutma yapılmasina bağlı olarak, lipit oksidasyonu ve antioksidan kapasite kayıpları gibi kimyasal bozulma reaksiyonları en düşük düzeyde gerçekleşmektedir (Rao vd., 2014).

Kurutma işlemi gidalarda patojen ve bozulmaya neden olan mikroorganizmaların faaliyetlerini durdurmakla ve sayılarını azaltmakla birlikte, tek başına gıda güvenliğini sağlayamamakta ve geriye kalan mikroorganizmalar tüketicide sağlik sorunlarına ve üründe bozulmalara neden olabilmektedir (Heldman ve Lund, 2006). Patojenlerin canlı kalma riskini ortadan kaldırmak amaciyla, etlerin kurutulmadan önce merkez sıcaklığının $71.1^{\circ} \mathrm{C}$ olmasını sağlayan 1 sıl işleme yani pastörizasyon işlemine tabi tutulması önerilmektedir (Calicioglu vd., 2002; 2003). Sicak su, buhar, buhar-vakum ve yüksek basınç uygulaması et ve et ürünlerinde yaygin olarak kullanılan pastörizasyon yöntemleridir (Andrés vd., 2006; Trivedi vd., 2007).

Literatürde tavuk göğüs etinin kurutulmasinda farklı yöntemlerin uygulandığı birçok çalışma mevcuttur. Kumar vd. (2019) tepsili kurutucuda farklı sıcaklıklarda kuruttukları tavuk göğüs eti dilimleri için, optimum sicaklık-zaman kombinasyonunu $70^{\circ} \mathrm{C}$ ve 5 saat olarak 
belirlemişlerdir. Optimum sicaklikta kurutulan örneklerde daha düşük nem içeriği (\%7.13), $a_{w}$ değeri (0.45) ve daha iyi rehidrasyon yeteneği gözlenmiştir. Teng vd. (2019), yaptıkları çalışmada tavuk göğüs etini sprey kurutma, vakum kurutma, mikrodalga-vakum kurutma ve kızlötesi-vakum kurutma yöntemleri ile kurutmuşlar ve elde ettikleri toz ürünün higroskopik ve fizikokimyasal özelliklerini araştırmışlardır. Bu çalışmada nem absorpsiyonunu azaltmada ve tavuk tozlarinin duyusal kalitesinin korunmasinda mikrodalgavakum kurutma yönteminin olumlu bir etkiye sahip olduğu belirlenmiştir. Başka bir çalşsmada, tavuk göğüs eti vakum kurutma ve mikrodalga vakum kurutma yöntemlerine kiyasla vakumradyo frekanslı kurutma ile daha hızlı kurutulmuş $(100 \mathrm{dk})$ ve bu yeni yöntemle elde edilen toz ürünlerde daha düşük higroskopiklik, daha yüksek su tutma kapasitesi ve daha iyi renk ve tat özellikleri tespit edilmiştir (Ran vd., 2019). Yeni bir kurutma yöntemi olarak süperkritik karbondioksitin ultrasonla birlikte uygulandığ 1 çalışmada ise, tavuk göğüs etinin besinsel kalitesi korunmuş ve ürünün mikrobiyel güvenliği sağlanmıştır (Morbiato vd., 2019). Yüksek kalitede minimal işlem görmüş kuru et ürünlerinin elde edilmesine yönelik alternatif bir diğer yöntem soğuk kurutma olup, tavuk etinin bu yöntemle kurutulduğu bir çalışmaya rastlanmamıştır. $\mathrm{Bu}$ çalışmada; soğuk kurutma sistemine asılan tavuk göğüs eti dilimleri kızgın buharla merkez sicakliklar1 $72^{\circ} \mathrm{C}$ olacak şekilde pastörize edildikten sonra farklı düşük sıcaklık $(10,15$ ve $\left.20^{\circ} \mathrm{C}\right)$ ve hava akış hızlarında $(3,4$ ve $5 \mathrm{~m} / \mathrm{s}$ ) kurutulmuştur. Daha sonra elde edilen ürünün bazı fiziksel, kimyasal, mikrobiyolojik ve duyusal özellikleri araştırılmışırır.

\section{MATERYAL VE YÖNTEM}

\section{Materyal}

Çalışma materyali olarak kullanılan tavuk göğüs etleri, Veli Cengiz Et Ürünleri Ltd. şirketinden (Antalya, Türkiye) temin edilmiştir. Göğüs etleri lif uzanışı yönünde yaklaşık 85 × 34 × $2 \mathrm{~mm}$ boyutlarında pastırma dilimleme makinasıla dilimlenmiştir. Kuru tuzlama işlemi $(\% 1$, w/w) uygulanan et dilimleri, tuz difüzyonunun gerçekleşmesi için $+4^{\circ} \mathrm{C}$ 'de her 15 dakikada bir çevrilerek 1 saat bekletilmiştir. Tuzlanmıs taze örneklerde tanımlayıcı analizler olarak; nem, ham protein, ham yağ, kül, tuz, $\mathrm{pH}$ ve $\mathrm{a}_{\mathrm{w}}$ değeri analizleri yapılmıştır. Farklı sıcaklık (10, 15 ve $20^{\circ} \mathrm{C}$ ) ve hava akış hızında (3, 4 ve $5 \mathrm{~m} / \mathrm{s}$ ) kurutma uygulamaları ( $3 \times 3)$ için, her grupta 25 et dilimi olmak üzere bir tekerrürde toplam 225 et dilimi kurutulmuştur.

\section{Tavuk göğüs eti dilimlerinin kurutulması}

$\mathrm{Bu}$ çalışmada minimal işlem görmüş ve gıda güvenliği açısından risk oluşturmayan kurutulmuş bir et ürünü üretmek için, soğuk kurutma sistemi (Patent No: TR 2015/10273) kullanılmıştır (Aykın-Dinçer ve Erbaş, 2018b). Soğuk kurutucuya asılmış olan et dilimlerine sırasıyla pastörizasyon ve kurutma işlemleri uygulanmıştır. Pastörizasyon işleminde, dilimlerin merkez sicaklığının $72^{\circ} \mathrm{C}$ olmasını sağlayacak düzeyde kızgin buhar kullanılmışır. Ön denemeler ile buhar uygulama sayss 5 ve her bir buhar uygulama süresi $40 \mathrm{~s}$ olarak belirlenmiştir. Pastörizasyondan sonra et dilimlerinin yüzeyinde ve kurutma ünitesi içerisinde biriken su, vakum uygulanarak atık toplama kabına alınmıs ve sistemden uzaklaştırılmışır.

Pastörize edilmiş tavuk göğüs eti dilimleri, aynı ünite içerisinde üç farklı düşük sicaklık $(10,15$ ve $20^{\circ} \mathrm{C}$ ) ve hava akış hızında (3, 4 ve $5 \mathrm{~m} / \mathrm{s}$ ) kurutulmuştur. Kurutma işlemine örneklerin mikrobiyel gida güvenliğinin sağlandığı ve duyusal olarak beğenildiği nem $(\approx \% 40)$ ve $\mathrm{a}_{\mathrm{w}}(\approx 0.90)$ değerlerine ulaşıncaya kadar devam edilmiştir. Kurutulmuş tavuk göğüs eti dilimleri, bazı kalite özellikleri araştırllıncaya kadar polietilen ambalajlarda aerobik koşullarda $+4^{\circ} \mathrm{C}$ 'de muhafaza edilmiştir.

\section{Kimyasal ve fiziksel analizler}

Örneklerin \% nem içeriği, etüvde (Memmert UNB 500, Schwabach, Almanya) $105^{\circ} \mathrm{C}^{\prime}$ de sabit tartıma gelinceye kadar kurutulması sonucunda gravimetrik olarak belirlenmiştir. Kül miktarı, örneklerin kül firınında (Elektro-magM 1813, İstanbul, Türkiye) $550^{\circ} \mathrm{C}$ 'de gri-beyaz bir kül rengi elde edilinceye kadar yakılması sonucunda gravimetrik olarak belirlenmiştir. Örneklerin $\mathrm{pH}$ değerleri, pH-metre cihazı (Hanna HI 2210, Woonsocket, RI, USA) kullanılarak ölçülmüsstür. 
Örneklerdeki ham protein miktarı, Kjeldahl yöntemi ile tespit edilen azot miktarının, protein çevirme faktörü olan 6.25 ile çarpilması ile tespit edilmiştir. Örneklerin ham yağ miktarı Soxhelet ekstraksiyon yöntemi ve tuz miktarı ise titrimetrik Mohr yöntemi ile belirlenmiştir (AOAC, 2000). Örneklerde lipit oksidasyonu sonucu meydana gelen tiyobarbitürik asit reaktif maddeleri (TBARS) değeri ise, spektrofotometrik olarak belirlenmiş ve sonuçlar $\mu \mathrm{mol}$ malondialdehit (MDA) $/ \mathrm{kg}$ örnek cinsinden ifade edilmiştir (Lemon, 1975).

Kurutulmuş örneklerin fiziksel özellikleri; $a_{w}$, renk, ağırlık kaybı, boyut değișimi ve kesilme kuvveti analizleri yapılarak belirlenmiştir. Örneklerin $\mathrm{a}_{\mathrm{w}}$ değeri, Decagon su aktivitesi ölçüm cihaz1 (Decagon Devices Inc., USA) kullanılarak $25^{\circ} \mathrm{C}^{\prime}$ de belirlenmiştir. Renk değerleri $\left(L^{*}, a^{*}, b^{*}\right)$, CR-400 Chromameter (Konica Minolta, Japonya) cihaz1 kullanilarak CIE (Commission Internationale de I'E Clairage) renk sistemine göre, örnek yüzeyindeki 5 farklı noktadan ölçülmüştür (Aykın-Dinçer ve Erbaş, 2019a).

Ağılık kaybı; et dilimlerinin kurutulmadan önceki ve kurutulduktan sonraki ağırlıkları arasındaki farkın, et dilimlerinin kurutulmadan önceki ağırlığına oranı (\%) olarak hesaplanmıştır. Boyut değişimi ise; ağırlık kaybı hesabına benzer şekilde, çiğ ve kurutulmuş et dilimlerinin kumpas ile ölçülen uzunluk, en ve kalınlık değerleri kullanılarak değerlendirilmiştir. Örneklerin kesilme kuvveti, tekstür analiz cihazında (TA.XT Plus, Stable Microsystems, UK) Warner Bratzler (HDP/BS) biçak seti kullanılarak tespit edilmiştir. Prob hız1, tetik kuvveti ve yük hücresi parametreleri sirasiyla $2 \mathrm{~mm} / \mathrm{s}, 10 \mathrm{~g}$ ve $50 \mathrm{~kg}$ olarak belirlenmiş ve analiz sonucunda elde edilen pikin maksimum değeri kesilme kuvveti $(\mathrm{N})$ olarak ifade edilmiştir (Aykın ve Erbaş, 2016).

\section{Mikrobiyolojik analizler}

Örneklerin mikrobiyel içeriklerini belirlemek amaciyla aseptik koşullarda $10 \mathrm{~g}$ örnek, $90 \mathrm{~mL}$ alkali peptonlu su ile homojenize edilmiş ve hedef alınan sayıya göre uygun dilüsyonlardan dökme yöntemi ile ekim yapılmıștır. Örneklerin toplam aerobik mezofilik bakteri (TAMB) ve toplam psikrofilik bakteri (TPB) sayımları için, Plate Count Agar besiyeri kullanılmış ve ekimi yapılan petriler sirasiyla $30^{\circ} \mathrm{C}$ 'de 48 saat ve $7^{\circ} \mathrm{C}$ 'de 10 gün inkübe edilmiştir. Maya-küf sayımı, Potato Dextrose Agar (PDA) içeren petrilerde $25^{\circ} \mathrm{C}$ 'de 5 gün inkübasyondan sonra yapılmıştır. Micrococcus/Staphylococcus sayımı için, Mannitol Salt Phenol-Red Agar (MSA) içeren petriler $30^{\circ} \mathrm{C}^{\prime} \mathrm{de}$ 48 saat inkübe edilmiştir. Laktik asit bakterileri (LAB) için, de Man Rogosa Sharpe Agar (MRS) ve Enterobacteriaceae için, Violet Red Bile Dextrose (VRBD) agar kullanılmıs ve ekimi yapılan petriler $30^{\circ} \mathrm{C}$ 'de anaerobik (Anaerocult A) olarak 48 saat inkübe edilmiştir. İnkübasyon sonunda $30-300$ arasında koloni içeren paralel petri kutularında sayım yapılmıştır (Maqsood vd., 2016).

\section{Duyusal değerlendirme}

Duyusal analiz, 8 kişilik bir panelist grubu tarafından beyaz floresan ile işıklandırılmış ve havalandırılmış bir odada yapılmıştır. Panelistler, Akdeniz Üniversitesi Mühendislik Fakültesi Gıda Mühendisliği Anabilim Dalı'nda yüksek lisans öğrenimine devam eden ve duyusal değerlendirme konusunda eğitimli kişiler arasından seçilmiştir. Örnekler panelistlere rastgele siralama yapilarak sunulmuş, değerlendirme esnasında bir önceki örnekten ağızda kalan tadı gidermek amaciyla panelistlere su ve ekmek verilmiştir. Duyusal analizde panelistler 9'lu hedonik skala (1: çok kötü, 9: çok iyi) kullanarak örneklerin görünüş, renk, koku, lezzet, yap1 (tekstür) ve genel beğeni özelliklerini değerlendirmiştir (Konieczny vd., 2007).

\section{İstatistiksel analiz}

Denemede kurutma sicakllğı $\left(10,15\right.$ ve $\left.20^{\circ} \mathrm{C}\right)$ ve hava akış hızı $(3,4$ ve $5 \mathrm{~m} / \mathrm{s})$ faktör olarak alınmış ve araştırma şansa bağlı tam bloklar deneme planına göre $3 \times 3$ faktöriyel düzende 2 tekerrürlü olarak yürütülmüştür. Elde edilen verilere SAS (V7, SAS Institute Inc., Cary, NC, USA) bilgisayar programı yardımıyla varyans analizi uygulanmış ve önemli bulunan faktörlere ait ortalamalar Duncan çoklu karşılaştırma testi ile karşılaştırılmıştır. Sonuçlar ortalama \pm standart hata şeklinde verilmiștir. 


\section{BULGULAR VE TARTIŞMA}

Tuzlanmıs taze et dilimlerinin fiziksel, kimyasal ve mikrobiyolojik analiz bulguları

Tuzlanmış taze tavuk göğüs eti diliminin bileşimi $\% 75.37 \pm 0.17$ nem, $\% 19.07 \pm 0.05$ ham protein, $\% 3.70 \pm 0.14$ ham yağ, $\% 1.85 \pm 0.03$ kül ve $\% 1.00 \pm 0.005$ tuz olarak belirlenmiştir. Tuzlanmış et dilimlerinin $\mathrm{pH}$ ve $\mathrm{a}_{\mathrm{w}}$ değeri ise sirasıyla, ortalama $6.11 \pm 0.007$ ve $0.92 \pm 0.001$ olarak belirlenmiştir. Bu çalısmada tavuk göğüs etinden hazırlanan et dilimlerinin bileşimi, literatür bulgularıla benzer sonuçlar göstermiştir (Bianchi vd., 2007; Cömert vd., 2016; Trembecká vd., 2017).

Tuzlanmış çiğ et diliminin mikrobiyel yükü; 5.81 log kob/g TAMB, 5.56 log kob/g TPB, $2.97 \mathrm{log}$ kob/g Micrococcus/Staphylococcus, 2.08 log kob/g $\mathrm{LAB}$ ve $4.70 \mathrm{log} \mathrm{kob} / \mathrm{g}$ maya-küf olarak tespit edilmiștir. Et dilimlerinin Enterobacteriaceae sayısı saptanabilir sınırın altında tespit edilmiştir. Çiğ örnekte sayımı yapılan mikroorganizma gruplar1 bozulmayla ilgili olsa da, genel olarak bozulma, mikrobiyel yük 7-8 log kob/g düzeyine ulaştı̆̆ında meydana gelmektedir (Vieira vd., 2009; Petit vd., 2014). Dolayısıyla tuzlanmış çiğ et dilimlerinin mikrobiyel yükü, bozulma için kabul edilen minimum değerin altındadır.

Soğuk kurutulmuş tavuk göğüs eti dilimlerinin nem, $\mathrm{a}_{\mathrm{w}}, \mathrm{pH}$ ve $T B A R S$ değerleri Farklı sıcaklık ve hava akış hızlarında soğuk kurutulmuş tavuk göğüs eti dilimlerinin nem, $a_{w}$, $\mathrm{pH}$ ve TBARS değerlerine ait bulgular Çizelge 1 'de verilmiştir. Varyans analizi sonuçlarına göre; kurutulmuş et dilimlerinin $\mathrm{a}_{\mathrm{w}} \mathrm{ve} \mathrm{pH}$ değeri üzerine sıcaklık, hava akış hızı ve sıcaklık x hava akış hızı interaksiyonunun önemli $(P>0.05)$ bir etkisinin olmadığı belirlenirken; nem içeriği üzerine hava akış hızı $(P<0.05)$ ve TBARS değeri üzerine ise, sıcaklık $(\mathrm{P}<0.05)$ ve hava akış hızı $(P<0.01)$ faktörlerinin önemli bir etkisinin olduğu tespit edilmiştir.

Soğuk kurutulmuş tavuk göğüs eti dilimlerinin nem içeriğinde, hava akış hızı artışına bağlı olarak bir artış tespit edilmiştir (Çizelge 1). Yüksek hava akış hızında $(5 \mathrm{~m} / \mathrm{s})$ kurutma sırasinda etin yüzeyinin daha çabuk kuruduğu ve buna bağlı olarak oluşan kabuğun, nemin dilim yüzeyinden uzaklaşmasını sınırlandırdığı değerlendirilmiştir. Soğuk kurutulmuş tavuk göğüs eti dilimlerinin ortalama nem içeriği $\% 37.38$, a değeri 0.886 ve pH değeri 6.15 olarak tespit edilmiştir. Dolayısıyla soğuk kurutulmuş tavuk göğüs eti dilimlerinin, nem içerikleri \%20-50 ve $a_{w}$ değerleri 0.70-0.90 aralı̆̆ında olan orta nemli gidalar (Huang ve Nip, 2001) sınıfinda yer aldığı belirlenmiştir. Benzer bir çalışmada, farklı sıcaklık $\left(10,15\right.$ ve $\left.20^{\circ} \mathrm{C}\right)$ ve hava akış hızlarında (1, 2, 3 ve $4 \mathrm{~m} / \mathrm{s})$ kurutulmuş kırmız1 et dilimlerinin nem, $a_{w}$ ve $\mathrm{pH}$ değerleri sirasiyla \%39.85, 0.89 ve 5.74 olarak tespit edilmiştir (Aykın-Dinçer ve Erbaş, 2019a). Tavuk etinin kurutulması üzerine yapılan bir çalışmada $\mathrm{da}$, nem ve $\mathrm{a}_{\mathrm{w}}$ değerlerinin sıcaklık artışından etkilenmediği, ortalama nem ve $a_{w}$ değerlerinin sırasıyla $\% 60.23$ ve 0.90 olduğu tespit edilmiştir (Jiang vd., 2016).

Soğuk kurutulmuş tavuk göğüs eti dilimlerinin TBARS değerinin, sıcaklık artışına bağlı olarak $22.34 \mu \mathrm{mol} \mathrm{MDA} / \mathrm{kg}$ değerinden $25.80 \mu \mathrm{mol}$ $\mathrm{MDA} / \mathrm{kg}$ değerine ve hava akış hızı artışına bağlı olarak $13.21 \mu \mathrm{mol} \mathrm{MDA} / \mathrm{kg}$ değerinden 32.92 $\mu \mathrm{mol} \quad \mathrm{MDA} / \mathrm{kg}$ değerine yükseldiği tespit edilmiştir (Çizelge 1). Sicaklığın yükselmesi ve hava akış hızı artışına bağlı olarak örneklerin daha yoğun bir şekilde oksijene maruz kalması gibi durumlar, örnekte bulunan yağ asitlerinin oksidasyonunu hızlandırmaktadır. Kurutulmuş et üzerine yapılan birçok çalışmada da TBARS değerinin sıcaklık ve hava akış hızı artışına bağlı olarak arttı̆̆ bildirilmiştir (Kilic, 2009; Gao vd., 2016; Jiang vd., 2016; Aykın-Dinçer vd., 2019).

\section{Soğuk kurutulmuş tavuk göğüs eti dilimlerinin renk değerleri}

Farklı sıcaklık ve hava akış hızlarında soğuk kurutulmuş tavuk göğüs eti dilimlerinin $L^{*}, a^{*}$ ve $b^{*}$ renk değerlerine ait bulgular Çizelge 2'de verilmiştir. Kurutulmuş tavuk göğüs eti dilimlerinin $L^{*}$ değeri üzerine kurutma sırasında uygulanan hava akış hızı $\mathrm{P}<0.05$ düzeyinde etkili bulunurken, sıcaklık ve sıcaklık x hava akış hızı interaksiyonunun önemli $(\mathrm{P}>0.05)$ bir etkisinin olmadiğ1 tespit edilmiştir. Kurutulmuş et dilimlerinin $a^{*}$ değeri üzerine sicaklık $\mathrm{P}<0.05$ düzeyinde etkili bulunurken, hava akış hızı ve 
sıcaklık x hava akış hızı interaksiyonunun önemli $(\mathrm{P}>0.05)$ bir etkisinin olmadığı belirlenmiştir. $b^{*}$ değeri üzerine ise, kurutma sirasinda uygulanan bu faktörlerin ve interaksiyonunun önemli $(\mathrm{P}>0.05)$ bir etkisinin olmadığ1 tespit edilmiştir.

Çizelge 1. Soğuk kurutulmuş tavuk göğüs eti dilimlerinin nem, $\mathrm{a}_{\mathrm{w}}, \mathrm{pH}$ ve TBARS değerleri Table 1. Moisture, $a_{m}, p H$ and TBARS values of cold dried chicken breast meat slices

\begin{tabular}{|c|c|c|c|c|}
\hline & $\begin{array}{l}\text { Nem }(\%) \\
\text { Moisture (\%) }\end{array}$ & $\begin{array}{l}\mathrm{a}_{\mathrm{w}} \\
\mathrm{a}_{w}\end{array}$ & $\begin{array}{l}\mathrm{pH} \\
\mathrm{pH}\end{array}$ & $\begin{array}{c}\text { TBARS } \\
(\mu \mathrm{mol} \mathrm{MDA} / \mathrm{kg}) \\
\text { TBARS } \\
(\mu \mathrm{mol} M D A / \mathrm{kg})\end{array}$ \\
\hline $10^{\circ} \mathrm{C}, 3 \mathrm{~m} / \mathrm{s}$ & $35.45 \pm 3.02$ & $0.894 \pm 0.004$ & $6.138 \pm 0.002$ & $12.24 \pm 0.74$ \\
\hline $10^{\circ} \mathrm{C}, 4 \mathrm{~m} / \mathrm{s}$ & $36.73 \pm 2.13$ & $0.883 \pm 0.003$ & $6.123 \pm 0.063$ & $22.91 \pm 1.74$ \\
\hline $10^{\circ} \mathrm{C}, 5 \mathrm{~m} / \mathrm{s}$ & $40.22 \pm 0.82$ & $0.883 \pm 0.010$ & $6.168 \pm 0.017$ & $31.87 \pm 4.01$ \\
\hline $15^{\circ} \mathrm{C}, 3 \mathrm{~m} / \mathrm{s}$ & $34.92 \pm 0.50$ & $0.882 \pm 0.008$ & $6.120 \pm 0.050$ & $13.63 \pm 0.07$ \\
\hline $15^{\circ} \mathrm{C}, 4 \mathrm{~m} / \mathrm{s}$ & $35.44 \pm 0.84$ & $0.885 \pm 0.013$ & $6.148 \pm 0.003$ & $24.13 \pm 0.57$ \\
\hline $15^{\circ} \mathrm{C}, 5 \mathrm{~m} / \mathrm{s}$ & $39.65 \pm 1.22$ & $0.891 \pm 0.002$ & $6.148 \pm 0.003$ & $30.76 \pm 0.00$ \\
\hline $20^{\circ} \mathrm{C}, 3 \mathrm{~m} / \mathrm{s}$ & $36.54 \pm 0.25$ & $0.880 \pm 0.006$ & $6.163 \pm 0.208$ & $13.77 \pm 0.67$ \\
\hline $20^{\circ} \mathrm{C}, 4 \mathrm{~m} / \mathrm{s}$ & $39.10 \pm 0.52$ & $0.884 \pm 0.013$ & $6.110 \pm 0.005$ & $27.50 \pm 0.52$ \\
\hline $20^{\circ} \mathrm{C}, 5 \mathrm{~m} / \mathrm{s}$ & $38.37 \pm 1.25$ & $0.890 \pm 0.003$ & $6.190 \pm 0.005$ & $36.12 \pm 0.11$ \\
\hline $\mathrm{T} \times \mathrm{A}$ & NS & $N S$ & NS & NS \\
\hline \multicolumn{5}{|c|}{$\begin{array}{l}\text { Sicaklik }\left(\mathrm{T},{ }^{\circ} \mathrm{C}, \mathrm{n}=6\right) \\
\text { Temperature }\left(T,{ }^{\circ} \mathrm{C}, n=6\right)\end{array}$} \\
\hline 10 & $37.47 \pm 1.33$ & $0.886 \pm 0.004$ & $6.143 \pm 0.019$ & $22.34^{b} \pm 3.77$ \\
\hline 15 & $36.67 \pm 1.03$ & $0.886 \pm 0.004$ & $6.138 \pm 0.014$ & $22.84^{b} \pm 3.16$ \\
\hline 20 & $38.00 \pm 0.60$ & $0.885 \pm 0.004$ & $6.154 \pm 0.056$ & $25.80^{a} \pm 4.12$ \\
\hline $\begin{array}{l}\text { Önem seviyesi } \\
\text { Significance }\end{array}$ & $N S$ & $N S$ & NS & $*$ \\
\hline \multicolumn{5}{|c|}{$\begin{array}{l}\text { Hava akış hızı }(\mathrm{A}, \mathrm{m} / \mathrm{s}, \mathrm{n}=6) \\
\text { Air flow rate }(A, m / s, n=6)\end{array}$} \\
\hline 3 & $35.64^{b} \pm 0.85$ & $0.885 \pm 0.004$ & $6.140 \pm 0.056$ & $13.21^{\mathrm{c}} \pm 0.40$ \\
\hline 4 & $37.09 \mathrm{ab} \pm 0.91$ & $0.884 \pm 0.005$ & $6.127 \pm 0.018$ & $24.84^{b} \pm 1.00$ \\
\hline 5 & $39.41^{a} \pm 0.61$ & $0.888 \pm 0.003$ & $6.168 \pm 0.009$ & $32.92^{\mathrm{a}} \pm 1.46$ \\
\hline $\begin{array}{l}\text { Önem seviyesi } \\
\text { Significance }\end{array}$ & * & NS & NS & $* *$ \\
\hline
\end{tabular}

a,b,c Sütun içindeki farklı harflerle gösterilen ortalama değerler, farklılıkları göstermektedir.

${ }_{a, b, c}$ Means with different letters within the column indicate differences.

NS Önemli bir farklılık bulunmamaktadır $(\mathrm{P}>0.05)$; * $\mathrm{P}<0.05 ; * * \mathrm{P}<0.01$

NS Not Significant $(P>0.05) ; * P<0.05$; ** $P<0.01$ 
Çizelge 2. Soğuk kurutulmuş tavuk gögüs eti dilimlerinin renk değerleri Table 2. Color values of cold dried chicken breast meat slices

\begin{tabular}{lccc}
\hline & $L^{*}$ & $a^{*}$ & $b^{*}$ \\
\hline $10^{\circ} \mathrm{C}, 3 \mathrm{~m} / \mathrm{s}$ & $67.00 \pm 0.41$ & $6.12 \pm 0.25$ & $22.29 \pm 3.12$ \\
$10^{\circ} \mathrm{C}, 4 \mathrm{~m} / \mathrm{s}$ & $67.04 \pm 0.22$ & $5.73 \pm 0.05$ & $23.42 \pm 1.81$ \\
$10^{\circ} \mathrm{C}, 5 \mathrm{~m} / \mathrm{s}$ & $69.25 \pm 0.26$ & $5.32 \pm 0.23$ & $22.98 \pm 0.72$ \\
$15^{\circ} \mathrm{C}, 3 \mathrm{~m} / \mathrm{s}$ & $66.13 \pm 1.89$ & $6.52 \pm 0.28$ & $22.20 \pm 1.82$ \\
$15^{\circ} \mathrm{C}, 4 \mathrm{~m} / \mathrm{s}$ & $66.90 \pm 0.05$ & $6.32 \pm 1.12$ & $23.72 \pm 0.27$ \\
$15^{\circ} \mathrm{C}, 5 \mathrm{~m} / \mathrm{s}$ & $68.17 \pm 0.08$ & $6.17 \pm 0.00$ & $22.96 \pm 0.21$ \\
$20^{\circ} \mathrm{C}, 3 \mathrm{~m} / \mathrm{s}$ & $66.61 \pm 0.94$ & $7.08 \pm 0.25$ & $23.18 \pm 0.51$ \\
$20^{\circ} \mathrm{C}, 4 \mathrm{~m} / \mathrm{s}$ & $66.92 \pm 0.72$ & $6.98 \pm 0.32$ & $23.58 \pm 0.04$ \\
$20^{\circ} \mathrm{C}, 5 \mathrm{~m} / \mathrm{s}$ & $68.09 \pm 0.87$ & $6.35 \pm 0.22$ & $23.33 \pm 0.61$ \\
$\mathrm{~T} \times \mathrm{A}$ & $N S$ & $N S$ & $N S$ \\
\hline Sicaklik $\left(\mathrm{T},{ }^{\circ} \mathrm{C}, \mathrm{n}=6\right)$ & & & \\
Temperature $\left(T,{ }^{\circ} \mathrm{C}, n=6\right)$ & $67.76 \pm 0.49$ & $5.72^{\mathrm{b}} \pm 0.17$ & $22.89 \pm 0.97$ \\
\hline 10 & $67.06 \pm 0.62$ & $6.34^{\mathrm{ab}} \pm 0.30$ & $22.96 \pm 0.55$ \\
15 & $67.21 \pm 0.48$ & $6.80^{\mathrm{a}} \pm 0.19$ & $23.36 \pm 0.22$ \\
20 & $N S$ & $*$ & $N S$ \\
Önem seviyesi & $N$ & & \\
Significance & & & \\
\hline
\end{tabular}

Hava akış hızı $(\mathrm{A}, \mathrm{m} / \mathrm{s}, \mathrm{n}=6)$

Air flow rate $(A, m / s, n=6)$

\begin{tabular}{lccc}
\hline 3 & $66.58^{\mathrm{b}} \pm 0.58$ & $6.57 \pm 0.21$ & $22.55 \pm 0.96$ \\
4 & $66.95^{\mathrm{b}} \pm 0.20$ & $6.34 \pm 0.38$ & $23.57 \pm 0.47$ \\
5 & $68.50^{\mathrm{a}} \pm 0.33$ & $5.94 \pm 0.22$ & $23.09 \pm 0.26$ \\
Önem seviyesi & $*$ & $N S$ & NS \\
Significance & & NS & \\
\hline
\end{tabular}

a,b Sütun içindeki farklı harflerle gösterilen ortalama değerler, farkllılkları göstermektedir.

${ }_{a, b}$ Means with different letters within the column indicate differences.

NS Önemli bir farklilık bulunmamaktadır $(\mathrm{P}>0.05) ; * \mathrm{P}<0.05$

NS Not Significant $(P>0.05) ; * P<0.05$

Duncan çoklu karşılaştırma testi sonuçlarına göre; sıcaklık artışına bağlı olarak kurutulmuş tavuk gögüs eti dilimlerinin $a^{*}$ değerinde önemli bir artış tespit edilmiştir. Etin kurutulması sırasında kas proteinlerinin amin grupları ile bağ dokuda bulunan indirgen şekerler arasında meydana gelen esmerleşme reaksiyonu sonucunda oluşan koyu renkli pigmentlerin, bu artışın nedeni olabileceği değerlendirilmiştir. Nathakaranakule vd. (2007) tarafindan yapilan bir çalışmada da kurutma sıcaklığ1 arttıkça, tavuk göğüs eti dilimlerinin $a^{*}$ değerinin arttığı bildirilmiştir. Hava akış hızındaki artışa bağlı olarak, soğuk kurutulmuş et dilimlerinin $L^{*}$ değerinde önemli bir artış belirlenmiştir. Bu artışın, yüksek hava akış hızında kurutma sirasinda koyu renkli pigmentlerin daha çok oksijene maruz kalmasindan ve bunun sonucunda renklerinin açılmasından kaynaklandığ1 düşünülmüştür.

Soğuk kurutulmuş tavuk göğüs eti dilimlerinin ağırlık kaybı, boyut değişimi ve kesilme kuvveti

Kurutulmuş tavuk gögüs eti dilimlerinin ağırlık kaybı ve en azalışı üzerine kurutma sırasında uygulanan sıcaklık, hava akış hızı ve sıcaklık $\mathrm{x}$ hava akış hızı interaksiyonunun önemli $(P>0.05)$ bir etkisinin olmadığı tespit edilmiştir. Uzunluk ve kalınlık azalısı üzerine kurutma sırasında uygulanan sıcaklık ve hava akış hızı önemli ( $P$ $<0.05, \quad P<0.01)$ düzeyde etkili bulunurken, sıcaklık x hava akış hızı interaksiyonunun önemli $(P>0.05)$ bir etkisinin olmadığ tespit edilmiştir (Çizelge 3). 
Çizelge 3. Soğuk kurutulmuş tavuk göğüs eti dilimlerinin fiziksel özellikleri Table 3. Physical properties of cold dried chicken breast meat slices

\begin{tabular}{|c|c|c|c|c|c|}
\hline & $\begin{array}{c}\text { Ağırlık kayb1 } \\
(\%) \\
\text { Weight loss } \\
(\%)\end{array}$ & $\begin{array}{c}\text { Uzunluk azalış1 } \\
(\%) \\
\text { Decrease in length } \\
(\%)\end{array}$ & $\begin{array}{c}\text { En azaliş1 } \\
(\%) \\
\text { Decrease in width } \\
(\%)\end{array}$ & $\begin{array}{c}\text { Kalınlık azalış1 } \\
(\%) \\
\text { Decrease in thickness } \\
(\%)\end{array}$ & $\begin{array}{c}\text { Kesilme kuvveti } \\
(\mathrm{N}) \\
\text { Cutting force } \\
(\mathrm{N})\end{array}$ \\
\hline $10^{\circ} \mathrm{C}, 3 \mathrm{~m} / \mathrm{s}$ & $55.68 \pm 1.16$ & $14.45 \pm 0.63$ & $31.86 \pm 0.25$ & $22.09 \pm 0.20$ & $16.96 \pm 0.70$ \\
\hline $10^{\circ} \mathrm{C}, 4 \mathrm{~m} / \mathrm{s}$ & $56.59 \pm 1.72$ & $17.06 \pm 0.75$ & $30.87 \pm 0.86$ & $18.24 \pm 3.88$ & $20.58 \pm 0.92$ \\
\hline $10^{\circ} \mathrm{C}, 5 \mathrm{~m} / \mathrm{s}$ & $55.86 \pm 0.95$ & $20.43 \pm 0.01$ & $31.36 \pm 0.06$ & $15.30 \pm 0.93$ & $21.79 \pm 0.24$ \\
\hline $15^{\circ} \mathrm{C}, 3 \mathrm{~m} / \mathrm{s}$ & $54.92 \pm 0.51$ & $13.19 \pm 1.40$ & $30.36 \pm 3.98$ & $24.34 \pm 1.52$ & $15.76 \pm 0.86$ \\
\hline $15^{\circ} \mathrm{C}, 4 \mathrm{~m} / \mathrm{s}$ & $54.16 \pm 1.86$ & $16.54 \pm 1.10$ & $30.53 \pm 3.11$ & $21.74 \pm 6.36$ & $18.08 \pm 1.64$ \\
\hline $15^{\circ} \mathrm{C}, 5 \mathrm{~m} / \mathrm{s}$ & $55.55 \pm 1.85$ & $18.37 \pm 0.00$ & $31.60 \pm 0.57$ & $18.13 \pm 0.06$ & $21.13 \pm 0.64$ \\
\hline $20^{\circ} \mathrm{C}, 3 \mathrm{~m} / \mathrm{s}$ & $55.76 \pm 0.25$ & $12.29 \pm 0.42$ & $32.04 \pm 0.90$ & $27.76 \pm 0.75$ & $8.84 \pm 0.99$ \\
\hline $20^{\circ} \mathrm{C}, 4 \mathrm{~m} / \mathrm{s}$ & $55.55 \pm 2.23$ & $14.55 \pm 0.29$ & $29.66 \pm 3.25$ & $25.80 \pm 1.80$ & $13.57 \pm 0.60$ \\
\hline $20^{\circ} \mathrm{C}, 5 \mathrm{~m} / \mathrm{s}$ & $54.65 \pm 1.97$ & $15.39 \pm 0.02$ & $30.39 \pm 3.53$ & $20.92 \pm 0.11$ & $19.16 \pm 0.29$ \\
\hline $\mathrm{T} \times \mathrm{A}$ & NS & NS & NS & NS & NS \\
\hline \multicolumn{6}{|c|}{$\begin{array}{l}\text { Sicakllk }\left(\mathrm{T},{ }^{\circ} \mathrm{C}, \mathrm{n}=6\right) \\
\text { Temperature }\left(T,{ }^{\circ} \mathrm{C}, n=6\right)\end{array}$} \\
\hline 10 & $56.04 \pm 0.61$ & $17.31^{\mathrm{a}} \pm 1.12$ & $31.36 \pm 0.29$ & $18.54^{b} \pm 1.62$ & $19.77^{a} \pm 0.97$ \\
\hline 15 & $54.88 \pm 0.74$ & $16.03^{a} \pm 1.06$ & $30.83 \pm 1.33$ & $21.40^{\mathrm{ab}} \pm 2.04$ & $18.32^{a} \pm 1.11$ \\
\hline 20 & $55.32 \pm 0.80$ & $14.08^{b} \pm 0.60$ & $30.70 \pm 1.34$ & $24.82^{\mathrm{a}} \pm 1.38$ & $13.85^{b} \pm 1.91$ \\
\hline $\begin{array}{l}\text { Önem } \\
\text { seviyesi } \\
\text { Significance }\end{array}$ & NS & $* *$ & NS & $*$ & $* *$ \\
\hline \multicolumn{6}{|c|}{$\begin{array}{l}\text { Hava akış hizı }(\mathrm{A}, \mathrm{m} / \mathrm{s}, \mathrm{n}=6) \\
\text { Air flow rate }(A, m / s, n=6)\end{array}$} \\
\hline 3 & $55.45 \pm 0.37$ & $13.31^{\mathrm{c}} \pm 0.57$ & $31.42 \pm 1.11$ & $24.73^{a} \pm 1.13$ & $13.85^{c} \pm 1.65$ \\
\hline 4 & $55.43 \pm 0.98$ & $16.05^{b} \pm 0.60$ & $30.35 \pm 1.20$ & $21.93^{\mathrm{ab}} \pm 2.41$ & $17.41^{b} \pm 1.39$ \\
\hline 5 & $55.35 \pm 0.77$ & $18.06^{a} \pm 0.92$ & $31.11 \pm 0.95$ & $18.11^{b} \pm 1.05$ & $20.69^{a} \pm 0.54$ \\
\hline $\begin{array}{l}\text { Önem } \\
\text { seviyesi } \\
\text { Significance }\end{array}$ & NS & ** & NS & $*$ & $* *$ \\
\hline $\begin{array}{l}\text { a,b,c Sütun için } \\
a, b, c \text { Means with } \\
\text { NS Önemli bi } \\
\text { NS Not Signifi }\end{array}$ & $\begin{array}{l}\text { farklı harfl } \\
\text { rent letters wit } \\
\text { rklilik bulur }\end{array}$ & $\begin{array}{l}\text { sterilen ortalar } \\
\text { column indicate } \\
\text { ktadir }(\mathrm{P}>0.0 \\
05 \text {; ** } P<0.0\end{array}$ & ğerler, farklıl & göstermektedir. & \\
\hline
\end{tabular}

Soğuk kurutma sisteminde tavuk göğüs eti dilimleri aynı nem içeriğine ulaşıncaya kadar kurutulduğu için, ağırllk kaybı üzerine faktörlerin önemli bir etkisinin olmadığı belirlenmiştir. Ancak, hızlı kuruyan örneklerde suyun hızlı bir şekilde uzaklaşmasına bağlı olarak protein yapısında daha fazla bir büzülme gerçekleşmiştir. $\mathrm{Bu}$ sonuçlara göre hızlı $\left(10^{\circ} \mathrm{C}\right.$ ve $\left.5 \mathrm{~m} / \mathrm{s}^{\prime} \mathrm{de}\right)$ kuruyan dilimlerin daha kısa ve daha kalın olduğu tespit edilmiştir. Yapılan bir çalışmada, aynı kurutma süresinde doğal yöntemle $\left(12-19^{\circ} \mathrm{C}\right.$ ve
\%55-85 nispi nem) kurutulmuş örneklere kıyasla, soğuk hava $\left(15^{\circ} \mathrm{C}, 1.5 \mathrm{~m} / \mathrm{s}\right.$ ve $\% 50-76$ nispi nem $)$ ile kurutulmuş et örneklerinin hacminin, daha hızlı su buharlaşması nedeniyle, daha fazla azaldığı bildirilmiştir (Zhang vd., 2017).

Farklı sıcaklık ve hava akış hızlarında soğuk kurutulmuş et dilimlerinin kesilme kuvveti değerine ait bulgular Çizelge 3'de verilmiştir. Kurutulmuş tavuk göğüs eti dilimlerinin kesilme kuvveti üzerine kurutma sirasinda uygulanan 
sıcaklık ve hava akış hızı $P<0.01$ düzeyinde etkili bulunurken, sıcaklık $\mathrm{x}$ hava akış hızı interaksiyonunun önemli $(P>0.05)$ bir etkisinin olmadığ1 tespit edilmiştir. Düşük sıcaklık ve yüksek hava akış hızında hızlı bir şekilde kuruyan örneklerin kesilme kuvvetinin daha yüksek olduğu belirlenmiştir. Çalışma sonuçlarına benzer şekilde, düşük sıcaklık $\left(10^{\circ} \mathrm{C}\right)$ ve yüksek hava akış hızında $(4 \mathrm{~m} / \mathrm{s})$ kurutulmuş kırmızı et dilimlerinin kesilme kuvveti değeri daha yüksek $(P<0.05)$ tespit edilmiştir (Aykın-Dinçer ve Erbaş, 2019a). Başka bir çalışmada da, $50^{\circ} \mathrm{C}$ 'de kurutulan et örneklerine göre $15^{\circ} \mathrm{C}$ 'de kurutulan örneklerin kesilme kuvveti değeri daha yüksek $(P<0.05)$ belirlenmiş olup, bu duruma yüksek sicaklıkta kollajen ve bağ dokunun çözünmesinin neden olabileceği bildirilmiştir (Jiang vd.,2016).

\section{Soğuk kurutulmuş tavuk göğüs eti dilimlerinin mikrobiyel yükleri}

Farklı sıcaklık ve hava akış hızlarında soğuk kurutulmuş et dilimlerinin mikrobiyel yüklerine ait bulgular Çizelge 4'de verilmiştir. Soğuk kurutulmuş tavuk gögüs eti dilimlerinin TAMB ve TPB içerikleri üzerine kurutma sırasında uygulanan hava akış hızı faktörü $\mathrm{P}<0.01$ düzeyinde etkili bulunurken, sicaklık ve sıcaklık $\mathrm{x}$ hava akış hızı interaksiyonunun önemli $(\mathrm{P}>0.05)$ bir etkisinin olmadı̆g tespit edilmiştir. Kurutulmuş et dilimlerinin Micrococcus/Staphylococcus, LAB ve maya-küf içerikleri üzerine ise; faktörlerin ve interaksiyonunun $(\mathrm{P}>0.05)$ önemli bir etkisinin olmadığı tespit edilmiştir.

Sıcaklık artışına bağlı olarak kurutulmuş et dilimlerinin mikrobiyel yüklerinde önemli bir değişim belirlenmezken; hava akış hızı artışına bağlı olarak TAMB ve TPB sayılarında önemli bir artış tespit edilmiştir. Hava akış hızı arttıkça artan oksijen miktarı, mikroorganizmaların gelişmesini desteklemiştir. Kurutma sıcaklığının etkisinin araştırıldığı diğer çalışmalarda, sıcaklık artışına bağlı olarak mikrobiyolojik kalitenin düştüğü tespit edilmiştir (Mukherjee vd., 2006; Kilic, 2009). Enterobacteriaceae sayıs1 ise, soğuk kurutulmuş tavuk göğüs eti dilimlerinde saptanabilir sinırın $(<1 \log \mathrm{kob} / \mathrm{g})$ altında tespit edilmiştir. Kurutma sırasında düşen $a_{w}$ değerine bağlı olarak, bu mikroorganizma grubunun canlılıklarını kaybetmiş olabileceği değerlendirilmiştir.

\section{Soğuk kurutulmuş tavuk göğüs eti dilimlerinin duyusal özellikleri}

Farklı sıcaklık ve hava akış hızlarında soğuk kurutulmuş tavuk gögüs eti dilimlerinin duyusal özelliklerine ait bulgular Çizelge 5'de verilmiştir. Varyans analizi sonuçlarına göre; kurutma sıcaklığının örneklerin koku hariç tüm duyusal özelliklerini, hava akış hızının ise yalnızca görünüş ve renk özelliklerini etkilediği $(P<0.05, P<0.01)$ tespit edilmiştir.

Görünüş, renk, lezzet, yap1 ve genel beğeni değerlerinin $10^{\circ} \mathrm{C}$ 'de kurutulmuş et dilimlerinde önemli düzeyde daha yüksek olduğu ve sicaklık arttıkça bu değerlerin azalma eğiliminde olduğu tespit edilmiştir. Bunun sebebi, sıcaklık artışına bağlı olarak ette bulunan birtakım enzimlerin aktivitesinin artması ve buna bağlı olarak et renginin kahverengileşmesi, arzu edilmeyen bazı tat ve aroma bileşiklerinin oluşmas 1 ve $20^{\circ} \mathrm{C}$ 'de yavaş kurumadan dolayı yapının yumuşak kalması olarak düşünülmüştür. Mukherjee vd. (2006) tarafindan yapılan bir çalışmada da kurutma sıcaklığındaki artış, et ürününün duyusal olarak daha az beğenilmesine neden olmuştur. Ayrıca, hava akış hızı arttıkça kurutulmuş et dilimlerinin görünüş ve renk değerlerinde önemli $(\mathrm{P}<0.01)$ bir artış tespit edilmiştir. Bu durumun, yüksek hava akış hızında ( $5 \mathrm{~m} / \mathrm{s})$ kurutma sırasında örneklerin renginin daha fazla açılmasından kaynaklandığı düşünülmektedir. Duyusal değerlendirme sonucunda, düşük sıcaklık $\left(10^{\circ} \mathrm{C}\right)$ ve yüksek hava akış hızında $(5 \mathrm{~m} / \mathrm{s})$ kurutulmuş tavuk göğüs eti dilimlerinin duyusal kalitelerinin daha yüksek olduğu tespit edilmiştir. 
Çizelge 4. Soğuk kurutulmuş tavuk göğüs eti dilimlerinin mikrobiyolojik kalitesi Table 4. Microbiological quality of cold dried chicken breast meat slices

\begin{tabular}{|c|c|c|c|c|c|}
\hline & $\begin{array}{c}\text { TAMB } \\
(\log \mathrm{kob} / \mathrm{g}) \\
\text { TAMB } \\
(\log c f u / g)\end{array}$ & $\begin{array}{c}\text { TPB } \\
(\log \mathrm{kob} / \mathrm{g}) \\
\text { TPB } \\
(\log c f u / g)\end{array}$ & $\begin{array}{c}\text { Micrococcus/ } \\
\text { Staphylococcus } \\
\text { (log kob/g) } \\
\text { Micrococcus/ } \\
\text { Stapbylococcus } \\
\text { (log cfu/g) }\end{array}$ & $\begin{array}{c}\mathrm{LAB} \\
(\log \mathrm{kob} / \mathrm{g}) \\
L A B \\
(\log c f u / g)\end{array}$ & $\begin{array}{c}\text { Maya-küf } \\
\text { (log kob/g) } \\
\text { Yeast-molds } \\
(\log c f u / g)\end{array}$ \\
\hline $10^{\circ} \mathrm{C}, 3 \mathrm{~m} / \mathrm{s}$ & $3.12 \pm 0.34$ & $1.62 \pm 0.62$ & $2.00 \pm 1.00$ & $1.00 \pm 0.00$ & $1.94 \pm 0.22$ \\
\hline $10^{\circ} \mathrm{C}, 4 \mathrm{~m} / \mathrm{s}$ & $2.83 \pm 0.16$ & $1.49 \pm 0.10$ & $2.91 \pm 0.04$ & $1.15 \pm 0.00$ & $1.88 \pm 0.29$ \\
\hline $10^{\circ} \mathrm{C}, 5 \mathrm{~m} / \mathrm{s}$ & $3.34 \pm 0.83$ & $1.91 \pm 0.11$ & $3.21 \pm 1.20$ & $1.39 \pm 0.09$ & $2.01 \pm 0.77$ \\
\hline $15^{\circ} \mathrm{C}, 3 \mathrm{~m} / \mathrm{s}$ & $2.66 \pm 0.26$ & $1.79 \pm 0.25$ & $1.89 \pm 0.50$ & $1.08 \pm 0.08$ & $1.59 \pm 0.00$ \\
\hline $15^{\circ} \mathrm{C}, 4 \mathrm{~m} / \mathrm{s}$ & $2.91 \pm 0.27$ & $2.12 \pm 0.18$ & $2.63 \pm 0.39$ & $1.54 \pm 0.39$ & $1.47 \pm 0.02$ \\
\hline $15^{\circ} \mathrm{C}, 5 \mathrm{~m} / \mathrm{s}$ & $4.41 \pm 0.40$ & $3.19 \pm 0.71$ & $2.82 \pm 1.67$ & $0.65 \pm 0.65$ & $1.79 \pm 0.07$ \\
\hline $20^{\circ} \mathrm{C}, 3 \mathrm{~m} / \mathrm{s}$ & $1.65 \pm 0.00$ & $1.27 \pm 0.27$ & $1.37 \pm 0.13$ & $1.00 \pm 0.00$ & $1.24 \pm 0.24$ \\
\hline $20^{\circ} \mathrm{C}, 4 \mathrm{~m} / \mathrm{s}$ & $1.60 \pm 0.21$ & $1.27 \pm 0.03$ & $1.30 \pm 0.30$ & $1.00 \pm 0.00$ & $1.08 \pm 0.08$ \\
\hline $20^{\circ} \mathrm{C}, 5 \mathrm{~m} / \mathrm{s}$ & $4.32 \pm 1.16$ & $2.86 \pm 0.38$ & $3.94 \pm 1.55$ & $1.84 \pm 0.06$ & $2.59 \pm 0.16$ \\
\hline $\mathrm{T} \times \mathrm{A}$ & NS & $N S$ & NS & NS & NS \\
\hline \multicolumn{6}{|c|}{$\begin{array}{l}\text { Sicaklik }\left(\mathrm{T},{ }^{\circ} \mathrm{C}, \mathrm{n}=6\right) \\
\text { Temperature }\left(T,{ }^{\circ} \mathrm{C}, n=6\right)\end{array}$} \\
\hline 10 & $3.09 \pm 0.25$ & $1.67 \pm 0.18$ & $2.71 \pm 0.46$ & $1.18 \pm 0.08$ & $1.94 \pm 0.22$ \\
\hline 15 & $3.32 \pm 0.37$ & $2.36 \pm 0.33$ & $2.45 \pm 0.50$ & $1.09 \pm 0.26$ & $1.61 \pm 0.06$ \\
\hline 20 & $2.52 \pm 0.65$ & $1.80 \pm 0.36$ & $2.20 \pm 0.68$ & $1.28 \pm 0.18$ & $1.63 \pm 0.31$ \\
\hline $\begin{array}{l}\text { Önem seviyesi } \\
\text { Significance }\end{array}$ & NS & $N S$ & NS & NS & NS \\
\hline \multicolumn{6}{|c|}{$\begin{array}{l}\text { Hava akış hizı }(\mathrm{A}, \mathrm{m} / \mathrm{s}, \mathrm{n}=6) \\
\text { Air flow rate }(A, m / s, n=6)\end{array}$} \\
\hline 3 & $2.47^{b} \pm 0.29$ & $1.56^{\mathrm{b}} \pm 0.21$ & $1.75 \pm 0.32$ & $1.03 \pm 0.03$ & $1.59 \pm 0.15$ \\
\hline 4 & $2.44^{b} \pm 0.29$ & $1.63^{\mathrm{b}} \pm 0.17$ & $2.28 \pm 0.34$ & $1.23 \pm 0.14$ & $1.47 \pm 0.17$ \\
\hline 5 & $4.02^{\mathrm{a}} \pm 0.44$ & $2.65^{\mathrm{a}} \pm 0.32$ & $3.32 \pm 0.70$ & $1.29 \pm 0.28$ & $2.13 \pm 0.25$ \\
\hline $\begin{array}{l}\text { Önem seviyesi } \\
\text { Significance }\end{array}$ & $* *$ & $* *$ & NS & NS & NS \\
\hline
\end{tabular}

TAMB: Toplam aerobik mezofilik bakteri; TPB: Toplam psikrofilik bakteri; LAB: Laktik asit bakterileri TAMB: Total aerobic mesophilic bacteria; TPB: Total psychrophilic bacteria; LAB: Lactic acid bacteria a,b Sütun içindeki farklı harflerle gösterilen ortalama değerler, farklılıkları göstermektedir.

${ }^{a, b}$ Means with different letters within the column indicate differences.

NS Önemli bir farklilik bulunmamaktadir ( $\mathrm{P}>0.05)$; ** $\mathrm{P}<0.01$

NS Not Significant $(P>0.05)$; ** $P<0.01$ 
Çizelge 5. Soğuk kurutulmuş tavuk göğüs eti dilimlerinin duyusal puanlar1

Table 5. Sensorial scores of cold dried chicken breast meat slices

\begin{tabular}{|c|c|c|c|c|c|c|}
\hline & $\begin{array}{l}\text { Görünüş } \\
\text { Appearance }\end{array}$ & $\begin{array}{l}\text { Renk } \\
\text { Color }\end{array}$ & $\begin{array}{c}\text { Koku } \\
\text { Odor }\end{array}$ & $\begin{array}{l}\text { Lezzet } \\
\text { Flavor }\end{array}$ & $\begin{array}{l}\text { Tekstür/Yap1 } \\
\text { Structure }\end{array}$ & $\begin{array}{l}\text { Genel beğeni } \\
\text { Overall } \\
\text { acceptability }\end{array}$ \\
\hline $10^{\circ} \mathrm{C}, 3 \mathrm{~m} / \mathrm{s}$ & $7.17 \pm 0.00$ & $6.75 \pm 0.08$ & $6.83 \pm 0.00$ & $7.09 \pm 0.09$ & $7.25 \pm 0.08$ & $7.09 \pm 0.09$ \\
\hline $10^{\circ} \mathrm{C}, 4 \mathrm{~m} / \mathrm{s}$ & $7.42 \pm 0.09$ & $6.67 \pm 0.17$ & $6.92 \pm 0.09$ & $7.25 \pm 0.08$ & $7.33 \pm 0.00$ & $7.17 \pm 0.00$ \\
\hline $10^{\circ} \mathrm{C}, 5 \mathrm{~m} / \mathrm{s}$ & $7.42 \pm 0.09$ & $7.67 \pm 0.00$ & $7.50 \pm 0.17$ & $7.25 \pm 0.08$ & $7.42 \pm 0.09$ & $7.42 \pm 0.09$ \\
\hline $15^{\circ} \mathrm{C}, 3 \mathrm{~m} / \mathrm{s}$ & $6.33 \pm 0.00$ & $6.00 \pm 0.00$ & $6.25 \pm 0.42$ & $6.59 \pm 0.42$ & $6.33 \pm 0.00$ & $7.00 \pm 0.00$ \\
\hline $15^{\circ} \mathrm{C}, 4 \mathrm{~m} / \mathrm{s}$ & $6.59 \pm 0.09$ & $6.42 \pm 0.09$ & $7.08 \pm 0.75$ & $6.59 \pm 0.09$ & $6.59 \pm 0.09$ & $6.67 \pm 0.34$ \\
\hline $15^{\circ} \mathrm{C}, 5 \mathrm{~m} / \mathrm{s}$ & $7.00 \pm 0.00$ & $6.67 \pm 0.17$ & $6.58 \pm 0.25$ & $6.58 \pm 0.25$ & $6.67 \pm 0.17$ & $5.92 \pm 0.75$ \\
\hline $20^{\circ} \mathrm{C}, 3 \mathrm{~m} / \mathrm{s}$ & $6.00 \pm 0.33$ & $5.67 \pm 0.50$ & $6.67 \pm 0.67$ & $6.50 \pm 0.17$ & $6.17 \pm 0.50$ & $6.50 \pm 0.17$ \\
\hline $20^{\circ} \mathrm{C}, 4 \mathrm{~m} / \mathrm{s}$ & $6.17 \pm 0.00$ & $5.67 \pm 0.17$ & $6.50 \pm 0.67$ & $6.84 \pm 0.34$ & $6.84 \pm 0.34$ & $6.58 \pm 0.25$ \\
\hline $20^{\circ} \mathrm{C}, 5 \mathrm{~m} / \mathrm{s}$ & $6.50 \pm 0.17$ & $6.50 \pm 0.00$ & $6.59 \pm 0.92$ & $6.17 \pm 0.17$ & $6.42 \pm 0.25$ & $6.67 \pm 0.34$ \\
\hline $\mathrm{T} \times \mathrm{A}$ & NS & NS & NS & NS & NS & NS \\
\hline \multicolumn{7}{|c|}{$\begin{array}{l}\text { Sicaklik }\left(\mathrm{T},{ }^{\circ} \mathrm{C}, \mathrm{n}=6\right) \\
\text { Temperature }\left(T,{ }^{\circ} \mathrm{C}, n=6\right)\end{array}$} \\
\hline 10 & $7.33^{a} \pm 0.06$ & $7.03^{a} \pm 0.21$ & $7.08 \pm 0.14$ & $7.20^{a} \pm 0.05$ & $7.33^{a} \pm 0.04$ & $7.22^{a} \pm 0.07$ \\
\hline 15 & $6.64^{b} \pm 0.13$ & $6.36^{\mathrm{b}} \pm 0.13$ & $6.64 \pm 0.28$ & $6.58^{\mathrm{b}} \pm 0.13$ & $6.53^{b} \pm 0.08$ & $6.53^{b} \pm 0.29$ \\
\hline 20 & $6.22^{c} \pm 0.13$ & $5.95^{c} \pm 0.22$ & $6.58 \pm 0.34$ & $6.50^{\mathrm{b}} \pm 0.16$ & $6.48^{\mathrm{b}} \pm 0.21$ & $6.58^{b} \pm 0.12$ \\
\hline $\begin{array}{l}\text { Önem seviyesi } \\
\text { Significance }\end{array}$ & $* *$ & ** & $N S$ & $* *$ & $* *$ & $*$ \\
\hline \multicolumn{7}{|c|}{$\begin{array}{l}\text { Hava akış hizı }(\mathrm{A}, \mathrm{m} / \mathrm{s}, \mathrm{n}=6) \\
\text { Air flow rate }(A, m / s, n=6)\end{array}$} \\
\hline 3 & $6.50^{\mathrm{b}} \pm 0.24$ & $6.14^{b} \pm 0.24$ & $6.58 \pm 0.23$ & $6.72 \pm 0.17$ & $6.58 \pm 0.25$ & $6.86 \pm 0.13$ \\
\hline 4 & $6.72^{b} \pm 0.23$ & $6.25^{b} \pm 0.20$ & $6.83 \pm 0.28$ & $6.89 \pm 0.15$ & $6.92 \pm 0.17$ & $6.81 \pm 0.16$ \\
\hline 5 & $6.97^{\mathrm{a}} \pm 0.17$ & $6.95^{a} \pm 0.24$ & $6.89 \pm 0.32$ & $6.67 \pm 0.22$ & $6.83 \pm 0.21$ & $6.67 \pm 0.35$ \\
\hline $\begin{array}{l}\text { Önem seviyesi } \\
\text { Significance }\end{array}$ & ** & ** & $N S$ & NS & $N S$ & NS \\
\hline
\end{tabular}

a,b,c Sütun içindeki farklı harflerle gösterilen ortalama değerler, farklılıkları göstermektedir.

$a, b, c$ Means with different letters within the column indicate differences.

NS Önemli bir farklilik bulunmamaktadır $(\mathrm{P}>0.05)$; * $\mathrm{P}<0.05 ; * * \mathrm{P}<0.01$

NS Not Significant $(P>0.05)$; * $P<0.05$; ** $P<0.01$

\section{SONUÇ}

Bu çalışmada, farklı düşük sıcaklık $(10,15$ ve $\left.20^{\circ} \mathrm{C}\right)$ ve hava akış hızlarında $(3,4$ ve $5 \mathrm{~m} / \mathrm{s}$ ) kurutulmuş tavuk göğüs eti dilimlerinin ortalama nem içeriğinin $\% 37, \mathrm{a}_{\mathrm{w}}$ değerinin 0.89 ve $\mathrm{pH}$ değerinin 6.15 olduğu tespit edilmiştir. Dilimlerin TBARS değeri, sıcaklık ve hava akış hızı artışına bağlı olarak artmıştır. Hızlı $\left(10^{\circ} \mathrm{C}\right.$ ve $\left.5 \mathrm{~m} / \mathrm{s}^{\prime} \mathrm{de}\right)$ kuruyan dilimlerin daha kısa, kalın ve sert bir yapıya sahip olduğu tespit edilmiştir. Düşük hava akış hızında $(3 \mathrm{~m} / \mathrm{s})$ kurutulmuş örneklerde mikrobiyel kalitenin daha iyi olduğu belirlenirken; duyusal kalitenin $10^{\circ} \mathrm{C}$ ve $5 \mathrm{~m} / \mathrm{s}$ hava akış hızında kurutulmuş örneklerden yüksek olduğu tespit edilmiştir.

$\mathrm{Bu}$ sonuçlar, hem bilim insanlarını gıda üretiminde kullanılacak yeni teknolojilerin geliştirilmesi alanında çalışmaya teşvik etmekte hem de tüketicileri gida güvenliği sağlanmış ve minimal işlem görmüş et ürünlerini tercih etmeleri konusunda bilinçlendirmektedir.

\section{KAYNAKLAR}

Andrés, A.I., Adamsen, C.E., Møller, J.K.S., Ruiz, J., Skibsted, L.H. (2006). High-pressure treatment of dry-cured Iberian ham. Effect on colour and 
oxidative stability during chill storage packed in modified atmosphere. Eur Food Res Technol, 222: 486-491, doi: 10.1007/s00217-005-0176-x.

Anonim. (2019). Türk Gıda Kodeksi Et, Hazırlanmış Et Karışımları ve Et Ürünleri Tebliği (2018/52). Tarım ve Orman Bakanlığ1, 29 Ocak 2019 tarih ve 30670 sayll Resmi Gazete, Ankara.

AOAC. (2000). Association of Official Analytical Chemists, Official Methods of Analysis, 17th edition. AOAC, Washington DC.

Aykın Dinçer, E., Erbaş, M. (2018). Etin tuzlanması işleminde vakumlu emdirim tekniğinin kullanilmasi. Gida, 43(1): 139-150, doi: 10.15237/gida.GD17086.

Aykın-Dinçer, E., Erbaş, M. (2019a). Quality characteristics of cold-dried beef slices. Meat Sci, 155: 36-42, doi: 10.1016/j.meatsci. 2019.05.001.

Aykın-Dinçer, E., Erbaş, M. (2019b). Cold dryer as novel process for producing a minimally processed and dried meat. Innov Food Sci Emerg, In Press, doi: 10.1016/j.ifset.2019.01.006.

Aykın Dinçer, E., Erbaş, M. (2019c). Kurutulmuş et ürünlerinin kalite özellikleri. Grda, 44(3): 472482, doi: 10.15237/gida.GD18124.

Aykın-Dinçer, E., Kılıç-Büyükkurt, Ö., Erbaş, M. (2019). Influence of drying techniques and temperatures on drying kinetics and quality characteristics of beef slices. Heat Mass Transfer, In Press, doi: 10.1007/s00231-019-02712-z.

Aykın, E., Erbaş, M. (2016). Quality properties and adsorption behavior of freeze-dried beef meat from the Biceps femoris and Semimembranosus muscles. Meat Sci, 121: 272-277, doi: 10.1016/j.meatsci.2016.06.030.

Bianchi, M., Petracci, M., Sirri, F., Folegatti, E., Franchini, A., Meluzzi, A. (2007). The influence of the season and market class of broiler chickens on breast meat quality traits. Poultry Sci, 86(5): 959-963, doi: 10.1093/ps/86.5.959.

Calicioglu, M., Sofos, J.N., Samelis, J., Kendall, P.A., Smith, G.C. (2002). Destruction of acid- and non-adapted Listeria monocytogenes during drying and storage of beef jerky. Food Microbiol, 19: 545559, doi: 10.1006/fmic.2002.0510.
Calicioglu, M., Sofos, J.N., Samelis, J., Kendall, P.A., Smith, G.C. (2003). Effect of acid adaptation on inactivation of Salmonella during drying and storage of beef jerky treated with marinades. Int J Food Microbiol, 89: 51-65, doi: 10.1016/S0168-1605(03)00107-7.

Cömert, M., Şayan, Y., Kırkpınar, F., Bayraktar, Ö. H., Mert, S. (2016). Comparison of carcass characteristics, meat quality, and blood parameters of slow and fast grown female broiler chickens raised in organic or conventional production system. Asian-Australas J Anim Sci, 29(7): 987-997, doi: 10.5713/ajas.15.0812.

Doğan, H. (2001). Düşük Nem Oranlı Hava ile Kurutma, Teknoloji, 3-4: 23-29.

Gao, R., Yuan, L., Yu, M., Liu, W. (2016). Effects of heat pump drying parameters on the volatile flavor compounds in silver carp. I Aquat Food Prod T, 25(5): 735-744, doi: 10.1080/ 10498850.2014.923082.

Heldman, D.R., Lund, D.B. (2006). Food Dehydration. In: Handbook of Food Engineering, Okos, M.R. (chief ed.), CRC press, New York, the USA, pp. 601-744.

Huang, T.C., Nip, W.K. (2001). Intermediatemoisture meat and dehydrated meat. In: Meat Science and Applications, Hui, Y.H. (chief ed.), Marcel Dekker Inc., New York, the USA, pp. 403442.

Jiang, N., Xu, B., Zhao, L., Huang, M., Zhou, G. (2016). Effects of high-temperature-short time (HTST) drying process on proteolysis, lipid oxidation and sensory attributes of Chinese drycured chicken. CyTA-J Food, 14(3): 440-448, doi: 10.1080/19476337.2015.1124291.

Kilic, A. (2009). Low temperature and high velocity (LTHV) application in drying: Characteristics and effects on the fish quality. $J$ Food Eng, 91: 173-182, doi: 10.1016/ j.jfoodeng.2008.08.023.

Konieczny, P., Stangierski, J., Kijowski, J. (2007). Physical and chemical characteristics and acceptability of home style beef jerky. Meat Sci, 76: 253-257, doi: 10.1016/j.meatsci.2006.11.006.

Kumar, D., Tarafdar, A., Kumar, Y., Badgujar, P.C. (2019). Intelligent modeling and detailed 
analysis of drying, hydration, thermal, and spectral characteristics for convective drying of chicken breast slices.J Food Process Eng, e13087, doi: 10.1111/jfpe.13087.

Lemon, D.W. (1975). An Improved TBA Test for Rancidity New Series Circular. No:51. Halifax Laboratory, Halifax, Nova Scotia.

Maqsood, S., Al Haddad, N. A., Mudgil, P. (2016). Vacuum packaging as an effective strategy to retard off-odour development, microbial spoilage, protein degradation and retain sensory quality of camel meat. LWT - Food Sci Technol, 72: 55-62, doi: 10.1016/j.lwt.2016.04.022.

Morbiato, G., Zambon, A., Toffoletto, M., Poloniato, G., Dall'Acqua, S., de Bernard, M., Spilimbergo, S. (2019). Supercritical carbon dioxide combined with high power ultrasound as innovate drying process for chicken breast. $J$ Supercrit Fluid,147: 24-32, doi: 10.1016/ j.supflu.2019.02.004.

Mukherjee, R.S., Chowdhury, B.R., Chakraborty, R., Chaudhuri, U.R. (2006). Effect of fermentation and drying temperature on the characteristics of goat meat (Black Bengal variety) dry sausage. AfrJ Biotechnol, 5(16): 1499-1504.

Nathakaranakule, A., Kraiwanichkul, W., Soponronnarit, S. (2007). Comparative study of different combined superheated-steam drying techniques for chicken meat. J Food Eng, 80(4): 1023-1030, doi: 10.1016/j.jfoodeng.2006.04.067.

Petit, T., Caro, Y., Petit, A. S., Santchurn, S. J., Collignan, A. (2014). Physicochemical and microbiological characteristics of biltong, a traditional salted dried meat of South Africa. Meat Sci, 96(3): 1313-1317, doi: 10.1016/j.meatsci. 2013.11.003.

Ran, X. L., Zhang, M., Wang, Y., Liu, Y. (2019). Vacuum radio frequency drying: a novel method to improve the main qualities of chicken powders. J Food Sci Technol, 56(10): 4482-4491, doi: 10.1007/s13197-019-03933-0.

Rao, M.A., Rizvi, S.S., Datta, A.K. (2014). Kinetic data for biochemical and microbiological processes during thermal processing. In: Engineering Properties of Foods, CRC Taylor \& Francis, London, the UK, pp. 633-666.

Teng, X., Zhang, M., Bhandari, B., Xu, J., Liu, Y. (2019). A comparative study on hygroscopic and physiochemical properties of chicken powders obtained by different drying methods. Dry Technol, 1-14, doi: 10.1080/07373937.2019.1679831.

Traffano-Schiffo, M.V., Castro-Giraldez, M., Fito, P.J., Balaguer, N. (2014). Thermodynamic model of meat drying by infrarred thermography. J Food Eng, 128: 103-110, doi: 10.1016/ j.jfoodeng.2013.12.024.

Trembecká, L., Haščík, P., Čuboň, J., Bobko, M., Cviková, P., Hleba, L. (2017). Chemical and sensory characteristics of chicken breast meat after dietary supplementation with probiotic given in combination with bee pollen and propolis. J Microbiol Biotechnol Food Sci, 7(3): 275280, doi: 10.15414/jmbfs.2017/18.7.3.275-280.

Trivedi, S., Reynolds, A.E., Chen, J. (2007). Use of a commercial household steam cleaning system to decontaminate beef and hog carcasses processed by four small or very small meat processing plants in Georgia. J Food Prot, 70 (3): 635-640, doi: 10.4315/0362-028X-70.3.635.

Vega, A., Fito, P., Andrés, A., Lemus, R. (2007). Mathematical modeling of hot-air drying kinetics of red bell pepper (var. Lamuyo). J Food Eng, 79: 1460-1466, doi: 10.1016/j.jfoodeng.2006.04.028.

Vieira, C., Diaz, M.T., Martinez, B., GarciaCachan, M.D. (2009). Effect of frozen storage conditions (temperature and length of storage) on microbiological and sensory quality of rustic crossbred beef at different states of ageing. Meat Sci, 83: 398-404, doi: 10.1016/j.meatsci. 2009.06.013.

Zhang, Z., Liu, Q., Wang, P., Liu, F., Gao, X. (2017). The rheological properties and structural changes of abalone meat with different drying methods. J Aquat Food Prod T, 26(2): 205-214, doi: 10.1080/10498850.2014.979383. 